\title{
NASA scientists rapped over experiments with animals
}

San Diego. Scientists working at the US National Aeronautics and Space Administration (NASA)'s Ames Research Center in California have been authorized to resume experiments with animals following a two-month suspension because of deficiencies in the way the experiments were being managed.

NASA administrators say they are working on ways to correct the problems that led to the suspension in March of all animal projects at the space science facility. Meanwhile, the federal Office of the Inspector General is reported to be investigating allegations raised - including claims that an attempt was made to purge records of botched animal experiments.

NASA officials say that the suspension was costly and threatened to delay some space flight experiments, including a monkey project scheduled to be launched in Animal experiments were resumed just in time to prevent projects from being switched to later space flights, said Kenneth A. Souza, assistant director for life sciences at Ames.

The shutdown of about 10 animal research projects, and the delay in the start of several others, came after the resignation in March of the facility's chief veterinarian, Sharon Vanderlip. Vanderlip complained that her efforts to ensure humane animal care and quality experiments had been thwarted by scientists and administrators.

"In my 15 years as a laboratory animal medicine veterinarian, I have never encountered the arrogance and blatant disregard for policies, regulations and animal welfare that I have witnessed at the NASA Ames Research Center," Vanderlip wrote in a letter of resignation to Daniel Goldin, NASA's administrator.

During her eight months in the job, Vanderlip said she found that animal experiments were bungled, that Ames did not have August 1996 on the Russian Biosatellite.

an approved assurance letter filed with the federal Office of Protection from Research Risks, and that some scientists and administrators undermined the activities of the facility's animal care and use committee.

When she attempted to remedy these defects, Vanderlip said she was harassed and intimidated by some Ames scientists and administrators. "I believe in animal research," said Vanderlip in her letter to Goldin. But she added that she was "sickened by the lack of respect for the spirit of the guidelines which ensure animal welfare, validate scientific findings and reassure the public."

William E. Berry, acting director of space science, declined to comment on Vanderlip's letter, attributing some of the problems to administrative "restructuring". But a panel of four outside experts - three veterinarians and a physiologist - called to review Vanderlip's claims, issued a report on 3 April agreeing with many of her charges.

One panel member, Martin J. Fettman, a veterinarian pathologist at Colorado State University, wrote in the report: "Many federally required procedures for care and use of animals weren't developed or documented, the animal care and use committee wasn't functioning correctly, some animal experiments weren't properly conducted, and some records on faulty experiments were purged".

The review panel also found that an Oregon-based company, TEAM Support Services Inc., which Ames had commissioned to manage its animal care facility, had significant administrative problems. The \$1.8-million contract with TEAM Support is up for renewal. TEAM Support officials have declined to comment.

Souza at Ames says that the centre now has a "corrective plan" which is being implemented.

Rex Dalton

\section{AAAS seeks to fill policy advice vacuum}

Washington. As the US Congress moves to shut its Office of Technology Assessment (OTA), the body that provides legislators with policy-related advice on scientific and technological issues, the American Association for the Advancement of Science (AAAS) is strengthening the assistance that it offers senators and congressmen.

The AAAS Center for Science, Technology and Congress last week held the first meeting of its advisory board, co-chaired by former congressmen John Brademas (Democrat, Indiana) and Bill Green (Republican, New York).

\section{Fusion research cuts may mean closure for Princeton facility}

Washington. Future prospects for the Princeton Plasma Physics Laboratory (PPPL) in New Jersey are looking bleak after a key congressional subcommittee voted to cut US spending on magnetic fusion research from $\$ 360$ million this year to $\$ 230$ million in 1996.

The House energy and water appropriations subcommittee, chaired by John Myers (Republican, Indiana), has not given any details of where cuts in fusion research should fall. But it has instructed the Department of Energy to work with Congress to map out a new programme that would fit the smaller budget.

PPPL currently spends $\$ 65$ million a year operating the Tokamak Fusion Test Reactor (TFTR), the main magnetic fusion experimental facility in the United States. It had hoped to start construction of a successor machine, the Tokamak Physics Experiment (TPX), next year, but laboratory officials recognizing that this was likely to be delayed for funding reasons, have been arguing instead for the continuation of TFTR to keep the laboratory alive.

Dale Meade, deputy director of PPPL, says that running costs for TFTR could be reduced to $\$ 60$ million and continued within the \$230-million budget, providing the United States cut back its other main fusion activity, namely its contribution to the design stage of the planned International Thermonuclear Experimental Reactor (ITER). "It depends how aggressively we continue with ITER," says Meade.

Meade says that a further three years of useful work could be done at TFTR, boosting the machine's power output from the 10.7 megawatts achieved last November to $20 \mathrm{MW}$, and gleaning more information about the behaviour of its mixed deuterium-tritium plasma fuel.

But influential House Republicans are ready to shut TFTR now. The House energy and environment subcommittee, chaired by Dana Rohrabacher has passed an authorizing bill that would do this, and Robert Walker, chair of the full House Science Committee, says the fusion programme should fund only ITER and a number of "small US programmes" to support it.

Earlier this year, a report from Congress's Office of Technology Assessment harshly criticized the lack of technical coordination between TPX and ITER, noting that TPX results would come too late to contribute to the ITER design. Democrat Congressman George Brown suggested that ITER might be delayed to use TPX results - a suggestion that has been angrily rejected by ITER management.

Colin Macilwain 